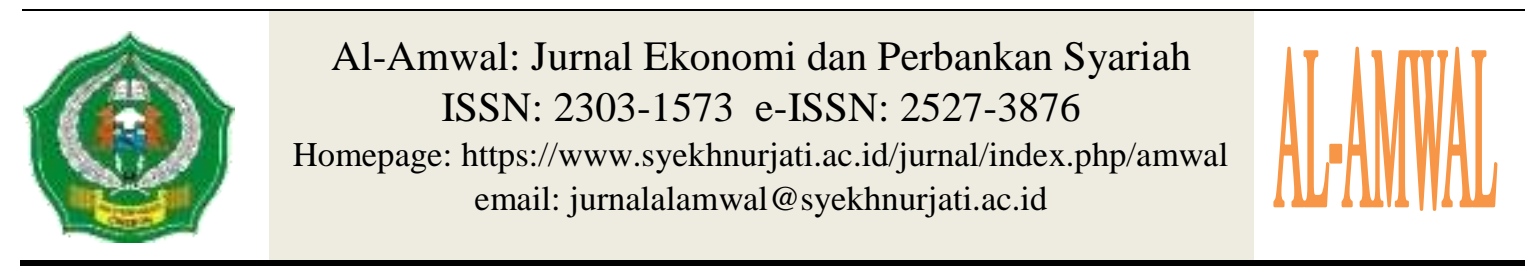

\title{
The Impact of Islamic Corporate Governance and Tabarru Fund on the Level of Sharia Insurance Health
}

\author{
Yafiul Firdaus \\ Fakultas Ekonomi dan Bisnis, Universitas Sebelas Maret \\ email: yafiulfirdaus@gmail.com \\ Falikhatun \\ Fakultas Ekonomi dan Bisnis, Universitas Sebelas Maret \\ email: falie.feuns17@gmail.com
}

\begin{abstract}
The purpose of this study to determine the impact of the number of sharia supervisory board, the number of the board of directors, the number of audit committees, and the Tabarru fund on the financial health level of Islamic insurance companies. This research was conducted on Sharia General Insurance companies and Sharia Life Insurance companies in Southeast Asia during the 2015-2019 period. The results of this research stated that the number of Sharia Supervisory Boards has a negative impact on the level of financial health, the number of the Board of Directors has a positive impact on the level of financial health, while the number of audit committees and the amount of Tabarru Funds has no impact on the level of financial health.
\end{abstract}

Keywords: audit committee, board of directors, islamic corporate governance, sharia supervisory board, tabarru fund.

\begin{abstract}
Abstrak
Tujuan penelitian ini adalah untuk mengetahui pengaruh jumlah anggota dewan pengawas syariah, jumlah anggota Direksi, jumlah anggota komite audit, dan dana Tabarru' terhadap tingkat kesehatan keuangan perusahaan asuransi syariah. Penelitian ini dilakukan pada perusahaan Asuransi Umum Syariah dan Perusahaan Asuransi Jiwa Syariah di Asia Tenggara selama periode 2015-2019. Hasil penelitian ini menyatakan bahwa jumlah anggota dewan pengawas syariah berpengaruh negatif terhadap tingkat kesehatan keuangan, jumlah anggoota direksi berpengaruh positif terhadap tingkat kesehatan keuangan, sedangkan jumlah anggota komite audit dan besaranya dana tabarru' tidak berpengaruh signifikan terhadap tingkat kesehatan keuangan.
\end{abstract}


Kata kunci : dana tabarru', dewan pengawas syariah, direksi, komite audit, Islamic corporate governance

\section{INTRODUCTION}

The level of financial health is very important in the company because it can be affect the company's operational activities. If an insurance company has a good level of financial health, policy owner will not hesitate to deposit their funds in the insurance company because they believe that the funds stored can be disbursed at any time. Research conducted by Gunawan (2019), shows that simultaneously the variable level of financial health has an influence on increasing the contribution of Islamic insurance companies in Indonesia.

Sharia institutions are institutions that in their governance apply Islamic values or commonly called Islamic corporate governance. Sharia insurance institutions are required to have a Sharia Supervisory Board. The Sharia Supervisory Board has the function of providing advice to sharia financial institutions to ensure that these financial institutions have implemented sharia principles and rules in carrying out their operational activities.

The Islamic Finance Development Report 2017 shows that the Southeast Asia region is one of the regions that has the fastest growing assets of the Sharia Non-Bank Financial Industry in the world. The total assets of sharia insurance in Southeast Asia is ranked 3rd, of the total assets of sharia insurance globally with a value of 200.242 billion USD. Countries such as Malaysia, Indonesia, and Brunei Darussalam are countries in Southeast Asia that have the highest Islamic insurance assets compared to other Southeast Asian countries.

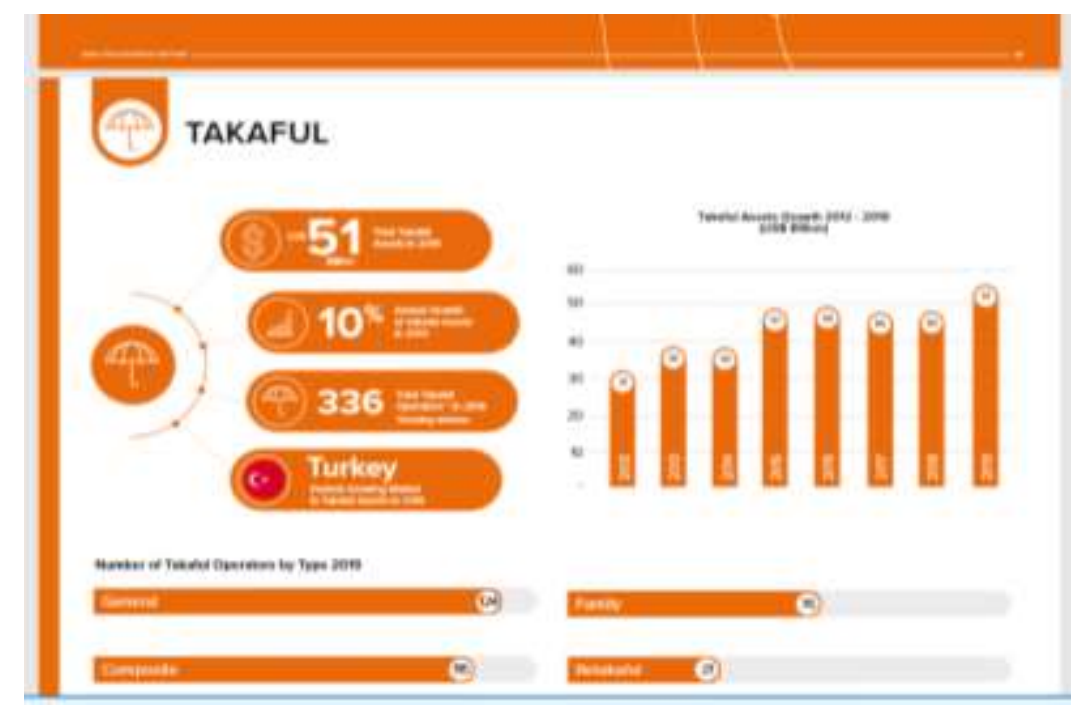

Figure 1. Percentage Growth of Takaful Assets

Source: Islamic Finance Development Report, 2020

Aslam \& Haron (2020), Baklouti (2020), Amalia et. al (2019), Almutairi \& Quttainah (2017) and Nomran et al. (2018), Mollah \& Zaman (2015) states that the number of members of the sharia supervisory board has a positive influence on the performance of Islamic banks. On the other hand, Khan and Zahid (2020), Pathan and Faff (2013), Eisenberg et al. (1998), Yermac (1996), and Judge and Zeithaml (1992) 
show that the number of member Islamic supervisory sharia boards has a negative effect on the financial performance of Islamic banks.

Furthermore, Amalia et. al (2019), Farag et al. (2018), Aprianingsih (2016), Santoso (2015), Adams and Mehran (2012), Andres and Vallelado (2008) shows that the number of member directors has a positive influence on the financial performance of Islamic banks. On the other hand, Aslam and Haron (2020), Zeineb and Mensi (2018), Mollah and Zaman (2015) and Goodstein et al. (1994), show that the number of member directors has a negative effect on the performance of Islamic banks. Rosada (2021), Yuniasary and Nurdin (2019), Pratiwi (2016), Damayanti and Chaniago (2014), Hisamuddin \& Tirta (2012), and Goodstein et al. (1994), state that there is an effect of the implementation of internal audit on the financial performance of Islamic commercial banks. On the other hand, Hidayah et. al (2020), Amalia et. al (2019), Santoso (2015), and Rohmah (2013), show that the application of internal audit and external audit functions does not have a significant effect on the financial health of Islamic banks.

This research is different from previous research, the independent variable used in this study is a combination of several previous research, namely Islamic corporate governance which is proxied by the number of members of the sharia supervisory board, the number of members of the board of directors, the number of members of the audit committee, and added a new variable, namely the amount of tabarru funds. Previous research was conducted on Islamic banks, so this research was conducted on Islamic insurance companies. This study uses a wider scope than previous studies, namely countries in Southeast Asia. The period of this research was carried out in the 2015-2019 period.

\section{LITERATURE REVIEW Agency Theory}

Agency theory is a version of game theory which describes the contract process between two or more people in which the parties involved in the contract try to get the best for themselves (Scott, 2000). An agency relationship occurs when one or more individuals referred to as principals employ another individual or organization, called agents, to perform a series of services and delegate decision-making power to these agents (Brigham and Houston, 2006). Agency relationships can arise when the principal and agent work together, where the principal will provide facilities and hand over policy and decision-making authority to the agent (Jensen and Mecklin, 1976). The agency theory literature argues that the independency characteristic has a significant impact on financial performance (Yermack, 1996; Bhagat and Black, 2002; Hermalin and Weisbach, 1991; Duchin et. al, 2010). Agency theory describes the relationship between management and shareholders. Shareholders submit facilities \& funds to manage the company, while managers are obliged to manage what the shareholders have entrusted to them. This is like Allah SWT said in Q.S. Al-anfaal (8) verse 27.

\section{Sharia Enterprise Theory}

Sharia Enterprise Theory is a refinement of the theory behind the previous enterprise theory. The important point that forms the basis for establishing the concept of sharia enterprise theory is that Allah SWT is the main source of trust and resources for stakeholders. These resources are united in the accountability of use, purposes, and methods determined by the giver of the Trust. Sharia enterprise theory tells us that in essence Allah SWT is the owner of the main power, while humans are only given the right to manage (khalifa fil ardhi) (Haryadi, 2010). A company is not only responsible 
to the owner of the company, but also to Allah SWT (Othman, et.al, 2009). The sharia enterprise theory argues that Allah SWT is the holder of the highest authority, so humans must be responsible for all their actions to humans and Allah SWT. This will make humams more integrity in carrying out their mandate that has been given to them (Triyuwono, 2007; Novarela and Sari, 2015; Hermawan and Rini, 2018). Putting the principles of balance and justice in accordance with the character of God (Mulawarman, 2009). This is in accordance with Q.S. As-Sad verse 26.

\section{Hypotheses}

\section{Sharia Supervisory Board and Financial Health Level}

An agency relationship can occur when one or more individuals commonly referred to as principals hire another individual/organization, referred to as an agent, to perform a number of services \& delegate the authority to make decisions to the agent (Brigham and Houston, 2006). For this reason, a supervisory board was formed which is responsible for supervising, advising, and ensuring management compliance with sharia principles. Mollah and Zaman (2015), Baklouti (2020), Amalia et. al (2019), Almutairi \& Quttainah (2017), and Nomran et al. (2018) states that the number of members of the sharia supervisory board has a positive influence on the financial performance of Islamic banks. Other studies conducted by Khan and Zahid (2020), Yermac (1996), Pathan and Faff (2013), and Eisenberg et al. (1998) actually explains that the sharia supervisory board has a negative influence on financial performance. Judge and Zeithaml (1992) stated that a large number of boards will only hinder decision making. The effective board size for a company is less than seven or eight people (Jensen, 1993). The large number of sharia supervisory boards can create differences of opinion in decision making, this will only lead to conflicts of opinion so that decision making becomes slow (Goodstein et al, 1993), the company will run less effectively. Even according to Nomran and Haron (2020) the relatively smaller number of sharia supervisory boards will have a significant positive effect. This indicates that the more the number of members of the supervisory board, the company will not run effectively and make the level of sharia insurance financial health decline.

$\mathrm{H}_{1}$ : the number of members of the sharia supervisory board has a negative effect on the financial health level of sharia insurance

\section{Board of Directors and Financial Health Level}

Sharia Enterprise Theory explains that the mandate from Allah can take various forms, one of which is human resources in the form of directors who can lead and manage the company well. The Board of Directors must be able to realize true justice for humans themselves, other humans, society as a whole, nature and the environment as well as justice for Allah as the ultimate owner in this world and the hereafter. The Board of Directors as the top leadership must certainly give the best in managing the company. Research conducted by Mollah \& Zaman (2015), Aslam \& Haron (2020), Zeineb and Mensi (2018) shows that the number of member directors has a negative influence on the financial performance of sharia banks. This is supported by Goodstein et al. (1994) and Judge and Zeithaml (1992) which show that a large number of directors will only hinder decision making. The results of different studies conducted by Farag et al. (2018), Aprianingsih (2016), Adams and Mehran (2012), Andres and Vallelado (2008), Santoso (2015), and Amalia et. al (2019) which states that the number of directors actually has a positive influence on the performance of Islamic banks. This 
is because there is a diversity of innovations in solving problems. Dalton et al (1999) and Felshental (2009) stated that a large number of directors is actually beneficial because it can have a lot of resources and expertise for the company. Hamza (2013) agrees that a large number of directors will provide a different perspective in innovating. In addition, many boards will have a lot of experience from different backgrounds in solving problems (Amalina Wan Abdullah et al, 2013). A large number of directors can actually provide a variety of innovations, a variety of ways of thinking in solving problems, and good analytical skills from each member. This allows the board of directors to manage the company's finances well. This shows that the more the number of existing members of the board of directors, the higher the level of sharia insurance financial health.

$\mathrm{H}_{2}$ : the number of members of the board of directors has a positive effect on the

financial health level of sharia insurance

\section{Audit Committee and Financial Health Level}

Agency theory explains that if there is a conflict within the company, the company can overcome it with the presence of a third party, namely the auditor. The auditor is an agent who is considered to be an intermediary between the interests of the principal and the agent in managing the finances contained in the company (Setiawan 2006). Research Hidayah et. al (2020), Amalia et. al (2019), Santoso (2015), and Rohmah (2013), show that the implementation of the internal audit and external audit functions does not have a significant effect on the financial Health of sharia banking. Other studies show different results, for example research by Rosada (2021), Aslam \& Haron (2020), Yuniasary \& Nurdin (2019, Pratiwi (2016), Wulandari (2016), and Hisamuddin and Tirta (2012), showing that there is a positive influence implementation of the audit committee function on the financial performance of sharia commercial banks. Independence is needed, this can improve financial performance (Dalton et al, 1998). The supervision carried out by the auditor on the board of directors will make the board of directors be careful in carrying out their duties. Damayanti \& Chaniago (2014) stated that the audit committee can influence the Health score of private commercial banks. The results of research by Krisdayanti et al (2019, Suseno (2019), and Utami (2018), also support other research that the implementation of an internal audit committee can have a significant influence on the financial performance of banks that have been registered with Bank Indonesia. The increase in the number of audit committees will be directly proportional to the financial transparency and governance of sharia insurance companies. The increase in the number of audit committees will minimize the occurrence of fraud in the company, this will allow the company to run optimally and maintain the level of financial health of sharia insurance. This shows that the more the number of audit committee members, the better the financial health of sharia insurance.

$\mathrm{H}_{3}$ : the number of members of the audit committee has a positive effect on the financial health level of sharia insurance

\section{Tabarru fund and Financial Health Level}

Sharia Enterprise Theory explains that the trust from Allah can take various forms, one of which is money. The money obtained by the company from the participants is a trust that must be managed and accounted for properly because the 
main essence is that everything in this world is a gift from Allah SWT. Research by Satata and Septiarini (2020), Sakinah (2019), Wardani (2019), Rahmawati (2018), Safitri and Suprayogi (2017), Novia (2019), Safitri (2016), Oktavianda (2017) and Dhaniati (2011) show that there is no significant effect between the growth of tabarru funds on the financial health of sharia life insurance. The results of other studies show different results. Research by Kholipah (2020) and Atmaja (2019) show that tabarru funds have a positive influence on the growth of sharia insurance assets. This is because there are additional funds owned by the company. These funds can be used for investment and other activities that can increase the company's profitability. This is supported by research by Yuniarti (2020), Pangestika (2019), Hindardjo and Mansuri (2016), which show that tabarru funds have a significant influence on the profitability of Islamic insurance companies. In addition to investment, tabarru funds can be used as a tool in case a claim occurs. This makes sharia insurance companies must have sufficient tabarru funds so that the company is in a safe condition. This happens if there is an insurance participant who makes a claim, the insurance company has sufficient funds to pay its obligations. Companies that can fulfill their obligations are a signal that the company has a good level of financial health. Thus, the greater the amount of tabarru funds, the higher the level of sharia insurance financial health.

$\mathrm{H}_{4}$ : the amount of tabarru funds has a positive effect on the financial health level of sharia insurance

The following is the conceptual framework that will be used in this research:

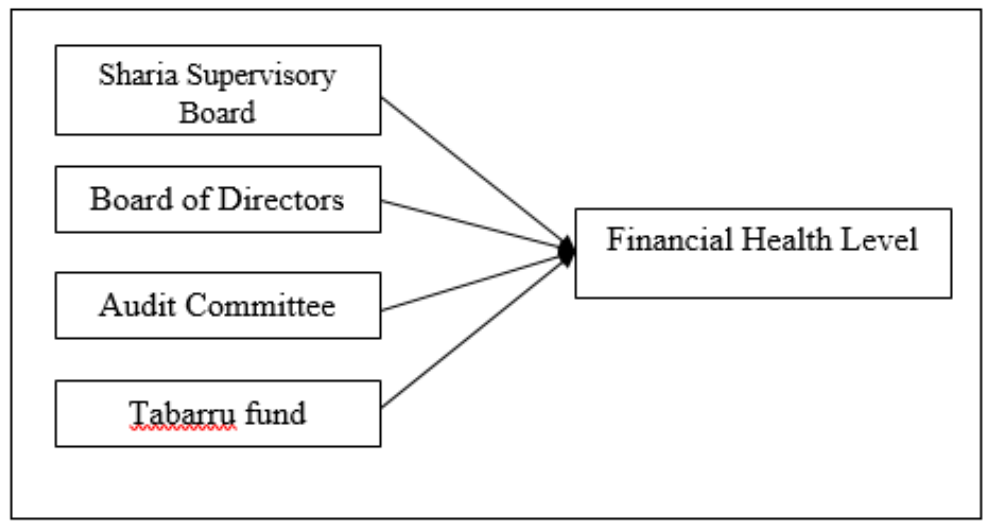

Figure 2. Research Model

\section{METHOD}

\section{Population and Sample}

The population in this study are all general sharia insurance companies and sharia life insurance companies in Indonesia, Malaysia, and Brunei Darussalam operating during 2015-2019. This study uses a purposive sampling method in determining the sample with predetermined criteria, namely 1) Islamic general insurance companies and sharia life insurance companies that issue financial statements for 2015-2019; 2) The published financial report has complete data in the form of a statement of financial position, income statement, and cash flow statement; 3) The company is still operating, not conducting mergers and acquisitions in the current year period; 4) The company has complete data regarding the variables used in the study. 
Table 1. Sampling Results

\begin{tabular}{lr}
\hline Sampling Criteria & Number \\
\hline Sharia insurance company registered with the Financial Services & 75 \\
Authority that publishes corporate governance reports or annual reports & \\
and financial reports for 2015-2019 (15 sharia insurance companies x 5 & \\
years) & 150 \\
Sharia insurance company registered with Bank Malaysia which publishes & \\
corporate governance reports or annual reports and financial reports for & \\
2015-2019 (30 sharia insurance companies x 5 years) & 20 \\
Sharia insurance company registered with Brunei Darussalam Monetary & \\
Authority which publishes corporate governance reports or annual reports & \\
and financial reports for 2015-2019 (4 sharia insurance companies x 5 & \\
years) & 245 \\
Total & 27 \\
Less: Outlier sample data & 218 \\
Total Number of observations & \\
\hline
\end{tabular}

Source: Data Processed (2021)

\section{Operational Definition of Variable Measurement Financial Health Level}

Return on Assets (ROA) is the ratio used to measure the company's capability to generate profit (Mardiyanto, 2009:196). This ratio shows the return on activities carried out by the company. A positive ROA value indicates that the amount of revenue generated by the company is greater than the total expenses incurred. This is a signal that the company is good at managing company finances. The company is able to invest the money well so that it can increase the probability of the company. The research of Billah \& Fianto (2021) shows that the profit generated by the company is a signal of the level of financial health of a company that has the ability to maintain its viability. The calculation of ROA follows previous research conducted by Billah and Fianto (2021).

$$
R O A=\frac{\text { Net Income }}{\text { average of total aset }}
$$

\section{Sharia Supervisory Board}

The Sharia Supervisory Board is the board responsible for providing advice to the board of directors, as well as supervising banking activities in accordance with sharia legal principles (PBI No. 11/3/2009 Article 47 paragraph 1). The variable of the Sharia Supervisory Board is measured by looking at the number of sharia supervisory boards which can be seen in the report on the implementation of Good Corporate Governance by each sharia insurance company. This measurement refers to the calculations put forward by Aslam \& Haron (2020) and Mollah \& Zaman (2015)

\section{Directors}

$$
S S B=\Sigma \text { Sharia Supervisory Board }
$$

The Board of Directors is the party that carries out important functions, namely internal audit, risk management committee, and maintaining sharia commercial banks to comply with sharia insurance principles. The variable of Directors is measured by looking at the number of directors in the report on the implementation of Good Corporate Governance in each sharia insurance company. This measurement refers to the calculations put forward by Aslam and Haron (2020) \& Mollah and Zaman (2015) 


\section{Audit Committee}

\section{Director $=\Sigma$ Director}

The implementation of the audit committee for companies is a form of selfassessment of good corporate governance that must exist in a company. The ratio of the Audit Committee is measured by considering the number of audit committees formed by the company, which can be seen in the report on the implementation of Good Corporate Governance in each sharia insurance company. This measurement refers to the calculations proposed by Yuniasary and Nurdin (2019) and by Mollah and Zaman (2015).

\section{Tabarru fund}

$$
\text { Audit Committee }=\Sigma \text { Audit Committee }
$$

Tabarru funds are grants collected by participants as aid funds to help other participants who are in a disaster or difficulty (Puspitasari: 2012). The tabarru fund ratio is measured by looking at how much tabarru funds are owned by sharia insurance companies which can be seen in the financial statements of each sharia insurance company. This measurement refers to the calculation proposed by Oktavianda (2017) \& Novia (2019).

\section{Data analysis method}

$$
\text { Tabarru fund }=\Sigma \text { Log Tabarru fund }
$$

Data analysis methods used include descriptive statistical analysis, classical assumption test, and multiple linear regression analysis. The Stata 14 program is used as a data processing tool. Furthermore, the regression equation can be formulated as follows:

$\mathrm{ROA}=\alpha+\beta_{1} \mathrm{SSB}+\beta_{2}$ Director $+\beta_{3}$ Audit Committee $+\beta_{4}$ Tabarru fund $+\varepsilon$

\section{RESULT AND DISCUSSION}

The results of a descriptive analysis conducted on 218 general sharia insurance companies and sharia life insurance companies in Indonesia, Malaysia, and Brunei Darussalam, show that these results describe the overall research object in general. The average (mean) ROA is 2.43 . This shows that the average sharia insurance health in the sample companies is 2.43. This is a good signal for the company. Niki Lukviarman (2006:36) states that the industry standard ROA is $5.98 \%$ or 0.06 . So the average level of financial health of sharia insurance companies in Indonesia, Malaysia, and Brunei Darussalam is higher than what is set so that it can be concluded that the level of financial health of sharia insurance companies is in good condition. A positive ROA value also indicates that the amount of revenue generated by the company is greater than the total expenses incurred. This is a signal that the company is good at managing company finances. The company is able to invest the money well so that it can increase the probability of the company.

The results of descriptive statistical tests on the variable number of sharia supervisory boards showed an average value of 3.307339 with the highest score of 8 and the lowest 7. The Audit Committee variable showed an average value of 3.431193 with the highest score of 8 and the lowest 2. Furthermore, the Board of Directors variable had an average amounted to 5.573394 with the highest score of 12 and the lowest score of 1 . the average result of the number of sharia supervisory boards, directors, and audit committees having complied with the regulations stipulated by the government in Bank Indonesia Regulation No. 11/3/PBI/2009, DSN-MUI Regulation 
No. PER-01/DSN-MUI/X/2017, Bapepam Regulation Kep 643/BL/2012, and AAOIFI, namely 3 people.

Table 2. Descriptive Statistics

\begin{tabular}{lccclll}
\hline \multicolumn{1}{c}{ variable } & \multicolumn{1}{c}{ Obs } & Mean & Std. Dev & Min & Max \\
Independent & Variable & & & & \\
$\begin{array}{l}\text { SSB } \\
\text { Audit }\end{array}$ & 218 & 3.307339 & 1.752429 & 1 & 8 \\
$\begin{array}{l}\text { Committee } \\
\text { Director }\end{array}$ & 218 & 3.431193 & 1.037251 & 2 & 8 \\
$\begin{array}{l}\text { Tabarru } \\
\text { fund }\end{array}$ & 218 & 5.573394 & 2.246683 & 1 & 12 \\
$\begin{array}{l}\text { Dependent Variable } \\
\text { ROA }\end{array}$ & 25.93119 & 3.688159 & 16.81 & 42.84 \\
\hline
\end{tabular}

Source: Data Processed (2021)

\section{Normality test}

The results of the normality test show a probability value of 0.156 . This value is greater than $0.05(0.156>0.05)$, so it can be said that the data used is normally distributed.

Table 3. Normality Test Results

\begin{tabular}{lll}
\hline Smaller group & \multicolumn{1}{c}{ D } & \multicolumn{1}{c}{ P-value } \\
\hline Res & 0.0765 & 0.078 \\
Cummulative & -0.0548 & 0.270 \\
Combined K-S & 0.0765 & 0.156 \\
\hline Source: Data Processed (2021) &
\end{tabular}

\section{Multicollinearity Test}

A data is said to be free from multicollinearity if the value of VIF>5. From the results of the multicolline test, it was found that the VIF value of all independent variables had a value of $<5$, meaning that there was no muticolinarity in the model.

Table 4. Multicollinearity Test Results

\begin{tabular}{llr}
\hline \multicolumn{1}{c}{ Variable } & \multicolumn{1}{c}{ VIF } & 1/VIF \\
\hline SSB & 1.97 & 0.507709 \\
Audit Committee & 1.87 & 0.534331 \\
Director & 1.30 & 0.771520 \\
Tabarru fund & 1.26 & 0.794129 \\
\hline
\end{tabular}

\section{Heteroscedasticity Test}

Source: Data Processed (2021)

The test results obtained a probability value of $0.2805(\mathrm{p}>0.05)$. Therefore, the data from this study escaped the heteroscedasticity problem.

Table 5. Heteroscedasticity Test Results

\begin{tabular}{lc}
\hline chi2(1) & 1.16 \\
\hline Prob > chi2 & 0.2805 \\
\hline
\end{tabular}

Source: Data Processed (2021) 


\section{Autocorrelation Test}

In the Autocorrelation Test through the Durbin-Watson test, the criteria for passing autocorrelation are indicated by the value $\mathrm{du}>\mathrm{d}>(4-\mathrm{du})$. The value of Durbin Watson (d) in this study was 1.93 while the value of $\mathrm{dl}=-2$ and $\mathrm{du}=2 .-2<1.93<2$ then the value of Durbin Watson in this study met the criteria to pass.

\section{Model Selection Test}

The results of the chow test show that the probability value of $\mathrm{F}$ is 0.0000 , so the model chosen from the chow test is the fixed effect model. The next step is to conduct the Hausman test to determine the appropriate final model in the study. The results of the Hausman test show that the chi-square probability value is 0.1671 , so the model chosen from the Hausman test is a random effect model.

Table 6. Chow Test Result

\begin{tabular}{llll}
\hline Effects Test & Statistic & d.f. & Prob. \\
\hline Cross-section F & 4,585896 & $(51,177)$ & 0,0000 \\
\hline
\end{tabular}

Source: Data Processed (2021)

Table 7. Hausman Test Result

\begin{tabular}{llll}
\hline Test Summary & Chi-Sq. Statistic & Chi-Sq. d.f. Prob. \\
\hline Cross-section random & 6,463666 & 4 & 0,1671 \\
\hline
\end{tabular}

Source: Data Processed (2021)

\section{Hypothesis Testing Results}

The result of the R-Squared value is 0.1286 or $12.86 \%$. This states that the independent variables of the sharia supervisory board, directors, audit committee, tabarru funds can explain the dependent variable Return on Assets (ROA) of $12.86 \%$ while the remaining $87.14 \%$ can be explained by other variables outside of this study.

In the F test, the F-statistic probability value is $0.000000<\mathrm{F}$ significance value of 0.05 . it can be concluded that the independent variable can simultaneously affect the dependent variable ROA.

Coefecient value describes the relationship between the independent variable and the dependent variable. A negative Coefficient value illustrates that there is a negative relationship between the independent variable and the dependent variable.

Table 8. Hypothesis Test Results

\begin{tabular}{lllccc}
\hline Hypothesis & $\begin{array}{c}\text { Independent } \\
\text { Variable }\end{array}$ & $\begin{array}{c}\text { Dependent } \\
\text { Variable }\end{array}$ & Koef. & Prob. & description \\
\hline H1(-) & SSB & ROA & -0.7256248 & 0.000 & $\begin{array}{c}\text { Negative } \\
\text { Effect }\end{array}$ \\
H2(+) & Director & ROA & 0.2465722 & 0.043 & $\begin{array}{c}\text { Positive Effect } \\
\text { H3 }\end{array}$ \\
& Audit & ROA & -0.3025306 & 0.161 & No Effect \\
& Committee & & & & No Effect \\
H4(+) & Tabarru fund & ROA & 0.007347 & 0.905 & \\
R-Squared & & & 0.1286 & & \\
Adj R-Squared & & & 0.1122 & & \\
F-statistics & & 7.86 & & \\
Prob (F-statistics) & & 0.0000 & & \\
\hline Source:Data Procen
\end{tabular}

Source: Data Processed (2021) 


\section{The Influence of the Sharia Supervisory Board on Financial Health Level}

Table 6 shows the coefficient value of the sharia supervisory board variable of 0.725 and the prob value of 0.000 . This shows that the sharia supervisory board variable has a significant negative effect on the level of financial health. Thus, H1 is supported by the data. This is in line with the research of Khan \& Zahid (2020), Yermac (1996), Pathan and Faff (2013), Nomran \& Haron (2020), Eisenberg et al. (1998), Pramono and Widiarto (2019), Judge and Zeithaml (1992), and Boone et al. (2007) stated that the number of supervisory boards has a negative influence on financial performance. This result is consistent with agency theory which explains the vulnerability of conflicts of interest or differences in objectives if there are a number of people in an organization. This complicates policy formulation. Judge and Zeithaml (1992) and Goodstein et al. (1993) which states that a large board size will only hinder decision making. The average number of sharia supervisory boards in the data is three, this shows that the average number of sharia supervisory boards has met the DSN-MUI standard no. PER01/DSN-MUI/X/2017 and AAOIFI, totaling three people. This is also in line with research by Jensen (1993), that the effective board size for a company is less than seven or eight people. On the other hand, not all sharia supervisory boards are of good quality, so their presence in the company is not necessarily a guarantee to improve company performance (Mishra, 2020). Nomran and Haron (2020) explain that the smaller number of members of the sharia supervisory board has a significant positive effect. This result is also in agreement with Q.S. Al-anfaal (8) verse 27 which states that we must not betray the mandate entrusted to us.

\section{The Influence of the Board of Directors on Financial Health Level}

Table 6 shows the value of the regression coefficient on the directors variable is 0.246 . While the $\mathrm{p}$ value is 0.043 . This concludes that the directors variable has a significant positive effect on the level of financial health. Thus $\mathrm{H} 2$ is supported by the data. These results are consistent with the research conducted by Faraag et al. (2018), Grassa and Matoussi (2014), Aprianingsih (2016), Adams and Mehran (2012), Andres and Vallelado (2008), Santoso (2015), Amalia et. al (2019), and Rosenstein and Wyatt (1997) which show that the number of directors has a positive influence on the performance of Islamic banks. In addition, this result is in line with the Sharia Enterprise Theory which states that the board of directors must be able to realize true justice for humans themselves, other humans, society as a whole, nature and the environment as well as justice for Allah as the ultimate owner in this world and the hereafter. A director must Prioritize the commons rather than himself, this is in accordance with Q.S. Al-Hasyr (59) verse 9. A large number of directors will increase diversity in innovation. Dalton et al (1999) and Felshental (2009) explain that a large number of directors will be beneficial because they can have a lot of resources and expertise for the company. The average number of directors in the data is five, this indicates that the average number of directors has exceeded the standard set by Bank Indonesia Regulation No. 11/33/PBI/2009, which is three people. Hamza (2013) agrees that many directors will provide different perspectives in innovating. The large number of members of the board of directors can provide various insights, variety of problem solving, and good critical thinking abilities from each member. This allows the board of directors to manage the company's finances well. 


\section{The Influence of the Audit Committee on Financial Health Level}

Table 6 shows the value of the regression coefficient on the audit committee variable is -0.30 . While the $p$ value is 0.161 . This concludes that the audit committee variable has no effect on the level of financial health. Thus, H3 is not supported by the data. This is in line with research by Setiawan (2006), Hidayah et. al (2020), Rohmah (2013), Amalia et. al (2019), and Santoso (2015), while these results contradict the researches of Hisamuddin \& Tirta (2012), Rosada (2021), Aslam \& Haron (2020), Pratiwi (2016), Wulandari (2016), Suseno (2019), and Yuniasary and Nurdin (2019). This is also not in line with agency theory which states that if there is a conflict within the company, it can be resolved through the presence of a third party, namely the auditor. Auditors are parties who are described as intermediaries between principals and agents in the company's financial management (Setiawan 2006). These results indicate that the company has not implemented what is contained in the Q.S. Al-anfaal (8) verse 27 properly, namely using the mandate given as well as possible. The number of audit committees has no effect on the level of financial health because the company may only be limited to carrying out formalities in complying with Bapepam Regulation Kep 643/BL/2012 concerning the number of audit committee members in the company at least three people ( 1 person is an independent commissioner and 2 others from outside the company or outside the issuer). This can be seen in the data that the average number of audit committees in the company is 3 (three) people. The formality in complying with regulations makes the effectiveness of the number of audit members in carrying out their functions less than optimal, thus having an impact on the level of financial health. Thus, the company cannot improve the level of financial health properly.

\section{The Influence of Tabarru fund on Financial Health Level}

Table 6 shows the value of the regression coefficient on the variable Amount of tabarru funds is 0.007 . While the $\mathrm{p}$ value is 0.905 . This concludes that the variable amount of tabarru funds does not have a significant effect on the level of financial health. Thus H4 is not supported by the data. This is in line with research by Wardani (2019), Safitri and Suprayogi (2017), Rahmawati (2018), Satata \& Septiarini (2020), Sakinah (2019), Safitri (2016), Novia (2019), Dhaniati (2011), and Oktavianda (2017), while the results of this study contradict those of Atmaja (2019), Kholipah (2020), Yuniarti (2020), Hindardjo \& Mansuri (2016), and Pangestika (2019). This is also not in line with the Sharia Enterprise Theory which explains that the Trust from Allah can take various forms, one of which is in the form of money. These results indicate that the company has not implemented what is the word of Allah SWT in Q.S. As-Sad verse 26 well. This trust in the form of money must be managed properly in order to get benefits for the giver and recipient of the trust. The tabarru fund can function as a reserve fund that can be used to pay its obligations. If the claims are high, the company will need a large reserve of tabarru funds, this reduces the funds that should be reserved for investment activities. This results in the company not having sufficient funds to invest in order to increase the company's profitability. Thus, the company does not have a good level of financial health. Statement of Financial Accounting Standards 108 concerning accounting for sharia insurance transactions, paragraph 8 explains that the basic principles in sharia insurance are mutual help (ta'awun) and mutual support (takaful) between insurance participants. Please help in the language of the Qur'an called ta'awun is the core of all principles in sharia insurance (Sula, 2004:229). 


\section{CONCLUSION}

This study aims to obtain empirical evidence on the influence of Islamic corporate governance and Tabarru fund on the financial health of Islamic insurance companies in Southeast Asia in 2015-2019. The results of this study prove simultaneously that the variable number of members of the board of directors has a positive effect on the level of sharia insurance financial health. while the number of members of the sharia supervisory board has a negative effect on the level of financial health of sharia insurance. the number of members of the Audit Committee and the amount of Tabarru fund have no effect on the level of financial Health of sharia insurance.

This study has limitations that need to be considered. First, the proxies used in measuring Islamic corporate governance are only the number of members of the sharia supervisory board, the number of members of the board of directors, and the number of members of the audit committee, so further research is expected to be able to add other proxies such as education level and meeting frequency as well as add control variables. Second, this study only uses 3 countries in Southeast Asia, namely Indonesia, Malaysia, and Brunei Darussalam, so the next research is expected to expand the scope of the research, namely countries in Asia and Europe. Third, this research period is relatively short because it is only limited to 2015-2019, so further research is expected to increase the time span that will be used in research.

The contribution of this research is that it is hoped that this research can be a reference for the development of science, especially in the field of accounting about the influence of Islamic Corporate Governance and the amount of tabarru funds on the level of financial health of Islamic insurance companies using agency theory and sharia enterprise theory and can be used as a reference for regulators to update regulations related to Islamic Corporate Governance and tabarru funds.

\section{REFERENCES}

Abdullah, W. A. W., Percy, M., \& Stewart, J. (2013). Shari'ah disclosures in Malaysian and Indonesian Islamic banks: The Shari'ah governance system. Journal of Islamic Accounting and Business Research, 4(2), 100-131. https://doi.org/10.1108/JIABR-10-2012-0063.

Adams, R. B., \& Mehran, H. (2012). Bank board structure and performance: Evidence for large bank holding companies. Journal of financial Intermediation, 21(2), 243-267. https://doi.org/10.1016/j.jfi.2011.09.002

Almutairi, A. R., \& Quttainah, M. A. (2017). Corporate governance: evidence from Islamic banks. Social Responsibility Journal. 13(3), 601-624. https://doi.org/10.1108/SRJ-05-2016-0061

Amalia, F., Sasongko, N., \& Bawono, A. B. (2019). Pengaruh Karakteristik Islamic Corporate Governance, Intellectual Capital dan Keputusan Pendanaan Terhadap Kinerja Keuangan. The 9th University Research Colloqium (Urecol), $9(5)$.

Aprianingsih, Astri. (2016). Pengaruh Penerapan Good Corporate Governance, Struktur Kepemilikan dan Ukuran Perusahaan terhadap Kinerja Keuangan Perbankan yang Terdaftar di Bursa Efeke Indonesia Tahun 2011-2014. Yogyakarta : Program Studi Akuntansi Jurusan Pendidikan Akuntansi Fakultas Ekonomi Universitas Negri Yogyakarta 2016 
Aslam, E., \& Haron, R. (2020). Does Corporate Governance Affect the Performance of Islamic Banks? New Insight into Islamic Countries. Corporate Governance: The International Journal of Business in Society , 20 (6), 1073-1090. https://doi.org/10.1108/CG-11-2019-0350

Baklouti, I. (2020). Is the sharia supervisory board a friend or an enemy of Islamic banks?. Journal of Islamic Marketing. Https://doi.org/10.1108/JIMA-042020-0118.

Bhagat, S., \& Black, B. (2001). The non-correlation between board independence and long-term firm performance. J. Corp. L., 27, 231. Https://dx.doi.org/10.2139/ssrn.133808

Billah, F. A. M., \& Fianto, B. A. (2021). Pengaruh Islamic Corporate Governance Terhadap Kinerja Bank Syariah: Studi Empiris Indonesia dan Malaysia. Jurnal Ekonomi Syariah Teori dan Terapan, 8(2), 243-254. Https://doi.org/10.20473/vol8iss20212pp243-254.

Boone, A. L., Field, L. C., Karpoff, J. M., \& Raheja, C. G. (2007). The determinants of corporate board size and composition: An empirical analysis. Journal of financial Economics, 85(1), 66-101. Https://doi.org/10.1057/s41260-02000181-2.

Brigham, E. F., \& Houston, J. F. (2006). Fundamentals of financial management. Jakarta : Salemba Empat.

Dalton, D. R., Daily, C. M., Johnson, J. L., \& Ellstrand, A. E. (1999). Number of directors and financial performance: A meta-analysis. Academy of Management journal, 42(6), 674-686. Https://doi.org/10.5465/256988

Damayanti, D. D., \& Chaniago, H. (2015). Pengaruh Risiko Usaha dan Good Corporate Governance terhadap Skor Kesehatan Bank pada Bank Umum Swasta Nasional Devisa. Journal of Business and Banking, 4(2), 217-230). Https://10.14414/jbb.v4i2.373

De Andres, P., \& Vallelado, E. (2008). Corporate governance in banking: The role of the board of directors. Journal of banking \& finance, 32(12), 2570-2580. Https://doi.org/10.1016/j.jbankfin.2008.05.008

Dhaniati, Rina. (2011). Analisis pengaruh $R B C$, rasio underwriting, rasio hasil investasi, rasio penerimaan premi, dan rasio beban klaim terhadap laba perusahaan asuransi. Jakarta: Fakultas Ekonomi Universitas Gunadarma.

Duchin, R., Matsusaka, J. G., \& Ozbas, O. (2010). When are outside directors effective?. Journal of financial economics, 96(2), 195-214. Https://doi.org/10.1016/j.jfineco.2009.12.004

Eisenberg, T., Sundgren, S., \& Wells, M. T. (1998). Larger board size and decreasing firm value in small firms. Journal of financial economics, 48(1), 35-54. Https://doi.org/10.1016/S0304-405X(98)00003-8.

Farag, H., \& Mallin, C. (2017). Board diversity and financial fragility: Evidence from European banks. International Review of Financial Analysis, 49, 98-112. Https://doi.org/10.1016/j.irfa.2016.12.002

Felsenthal, D. S., \& Machover, M. (2009). A note on measuring voters' responsibility. Homo Oeconomicus, 26(2), 259-271.

Goodstein, J., Gautam, K. \& Boeker, W. (1994). The effects of board size and diversity on strategic change. Strategic Management Journal, 15: 241-250. https://doi.org/10.1002/smj.4250150305 
Gunawan, M. S. (2019). Pengaruh Tingkat Kesehatan Perusahaan Asuransi Terhadap Pertumbuhan Kontribusi Netto Studi Pada 6 Perusahaan Asuransi Syariah di Indonesia (Doctoral dissertation, UIN SMH BANTEN).

Hamza, H. (2013). Sharia governance in Islamic banks: effectiveness and supervision model. International Journal of Islamic and Middle Eastern Finance and Management Vol. 6 No. 3, pp. 226-237. https://doi.org/10.1108/IMEFM-022013-0021..

Haryadi, Bambang. 2010. Political Economy of Shariah Accounting (Membangun Teori Ekonomi Politik Akuntansi Syariíah). Malang: Pascasarjana Universitas Brawijaya.

Hermalin, B. E., \& Weisbach, M. S. (1991). The effects of board composition and direct incentives on firm performance. Financial management, 101-112. https://doi.org/10.2307/3665716.

Hermawan, S., \& Rini, R. W. (2018). Pengelolaan dana zakat, infaq, dan shadaqah perspektif Shariah Enterprise Theory. Riset Akuntansi dan Keuangan Indonesia, 1(1), 12-24. https://doi.org/10.23917/reaksi.v1i1.1974

Hidayah, R., Hidayah, N., \& Purnomo, D. E. (2020). Pengaruh Sharia Compliance dan Islamic Corporate Governance Terhadap Kesehatan Finansial Perbankan Syaria. Jurnal Neraca. Volume 16 Nomor 2, 1-25. https://doi.org/10.48144/neraca.v16i2.495.

Hindardjo, A., \& Mansuri, M. (2016). Pengaruh Dana Tabarru'dan Klaim Terhadap Profitabilitas Pada Perusahaan Asuransi PT. Prudential Unit Syariah Periode 2011-2015. Jurnal Asy-Syukriyyah, 17(1), 84-103.

Hisamuddin, Nur dan M. Yayang Tirta K. (2012). Pengaruh Good Corporate Governance Terhadap Kinerja Keuangan Bank Umum Syariah. Jurnal Program Studi Akuntansi (hlm. 109-138). Jember : Fakultas Ekonomi Universitas Jember.

Jensen, M. (1993). The modern industrial revolution, exit, and the failure of internal control systems. The Journal of Finance, 48: 831-880. https://doi.org/10.1111/j.1745-6622.1994.tb00244.x

Jensen, M. C., \& Meckling, W. H. (1976). Theory of the firm: Managerial behavior, agency costs and ownership structure. Journal of financial economics, 3(4), 305-360. https://doi.org/10.1016/0304-405X(76)90026-X

Judge, W. Q., \& Zeithaml, C. P. (1992). Institutional and strategic choice perspectives on board involvement in the strategic decision process. Academy of Management Journal, 35(4), 766-794. https://doi.org/10.2307/256315

Kholipah, L. (2020). Pengaruh klaim, investasi, dana tabarru'dan underwriting terhadap pertumbuhan aset perusahaan asuransi jiwa syariah tahun 20162018 (Doctoral dissertation, (Universitas Islam Negeri Walisongo Semarang).

Khan, I., Zahid, S. N. (2020). The impact of shari'ah and corporate governance on Islamic banks performance: evidence from Asia. International Journal of Islamic and Middle Eastern Finance and Management, 13(3), 483-501. https://doi.org/10.1108/IMEFM-01-2019-0003

Krisdayanti, Amin, dan Junaidi. (2019). Pengaruh Good Corporate Governance Terhadap Profitabilitas dan Kinerja Saham Perusahaan Perbankan yang 
Terdaftar Di Bursa Efek Indonesia. E-JRA Vol. 08 No. 05, 120-130. https://doi.org/10.14414/jbb.v1i1.148.

Mollah, S., \& Zaman, M. (2015). Shari'ah Supervision, Corporate Governance and Performance: Conventional vs. Islamic Banks. Journal of Banking and Finance, 58, 418-435. https://doi.org/10.1016/j.jbankfin.2015.04.030.

Mulawarman, A. D. (2009). Menggagas Laporan Keuangan Syari'ah Berbasis Trilogi Ma'isyah-Rizq-Maal. Tazkia Islamic Finance and Business Review, 4(1). http://dx.doi.org/10.30993/tifbr.v4i1.27

Nomran, N. M., Haron, R., \& Hassan, R. (2018). Shari'ah Supervisory Board Characteristics Effects on Islamic Banks' Performance: Evidence from Malaysia. International Journal of Bank Marketing , 36 (2), 290-304. https://doi.org/10.1108/IJBM-12-2016-0197

Nomran, N. M., Haron, R., \& Hassan, R. (2018). Shari'ah Supervisory Board Characteristics Effects on Islamic Banks' Performance: Evidence from Malaysia. International Journal of Bank Marketing , 36 (2), 290-304. https://doi.org/10.1108/IJBM-12-2016-0197.

Nomran, N. M., Haron, R. (2019). Dual board governance structure and multi-bank performance: A comparative analysis between Islamic banks in Southeast Asia and GCC countries. Corporate Governance (Bingley), 19(6), 1377-1402. https://doi.org/10.1108/CG-10-2018-0329.

Nomran, N. M., Haron, R. (2020). Shari'ah supervisory board's size impact on performance in the Islamic banking industry: An empirical investigation of the optimal board. Journal of Islamic Accounting and Business Research, 11(1), 110-129. https://doi.org/10.1108/JIABR-05-2017- 0070.

Nomran, N. M., Haron, R. (2020). A systematic literature review on Shari'ah governance mechanism and firm performance in Islamic banking. Islamic Economic Studies, 27(2), 91-123. https://doi.org/10.1108/IES-06-2019-0013.

Novarela, D., \& Sari, I. M. (2015). Pelaporan Corporate Social Responsibility Perbankan Syariah dalam Perspektif Shariah Enterprise Theory (SET). Jurnal Akuntansi dan Keuangan Islam, 3(2), 145-160.

Novia, S. (2019). Pengaruh Kontribusi Dana Tabarru' Terhadap Laba Perusahaan Periode 2013-2018 (Studi Pada Unit Syariah PT. Bumiputera Muda 1967). (Doctoral dissertation, UIN SMH BANTEN).

Oktavianda, F. A. (2017). Faktor-Faktor Yang Mempengaruhi Kesehatan Keuangan Perusahaan Asuransi Jiwa Syariah di Indonesia (yang terdaftar di OJK Periode 2012-2015). Jakarta: Universitas Islam Negeri Syarif Hidayatullah.

Othman, N. H., \& Rebolj, M. (2009). Challenges to cervical cancer screening in a developing country: the case of Malaysia. Asian Pac J Cancer Prev, 10(5), 747-751.

Pathan, S., \& Faff, R., (2013). Does board structure in banks really affect their performance?. Journal of Banking and Finance 37(5), 1573-1589. https://doi.org/10.1016/j.jbankfin.2012.12.016.

Pfeffer, J. (1972). Size and composition of corporate boards of directors: The organization and its environment. Administrative Science Quarterly, 17: 218229. https://doi.org/10.2307/2393956.

Pratiwi, A. (2016). Pengaruh Kualitas Penerapan Good Corporate Governance (GCG) Terhadap Kinerja Keuangan pada Bank Umum Syariah Di Indonesia (Periode 
2010-2015). Al-Tijary-Jurnal Ekonomi dan Bisnis Islam, 2 (1), 55-76. Sumber, 8(83), 8-89. https://doi.org/10.21093/21093

Rohmah, F. (2013). Pengaruh Mekanisme Corporate Governance Terhadap Manajemen Laba dan Dampaknya Terhadao Kinerja Keuangan Perusahaan(Doctoral dissertation, UPN Veteran Yogyakarta).

Rosada, A. (2021). The Effect of Good Corporate Governance Implementation on Islamic Bank Financial Performance. Management Analysis Journal, 10(1), 5561. https://doi.org/10.15294/maj.v10i1.44339

Safitri, E. K. (2016). Pengaruh Rasio Kesehatan Keuangan Dana Tabarru Terhadap Profitabillitas Pada Perusahaan Asuransi Syariah Di Indonesia Periode 20122014. (Doctoral dissertation, Universitas Airlangga).

Safitri, E. K., \& Suprayogi, N. (2017). Analisis Rasio Kesehatan Keuangan Dana Tabarru'Yang Mempengaruhi Profitabilitas Pada Asuransi Syariah di Indonesia (Periode 2012-2014). Jurnal Ekonomi Syariah Teori dan Terapan, 4(1), 73. http://dx.doi.org/10.20473/vol4iss20171pp73-88.

Sakinah, P. (2019). Pengaruh Tingkat Solvabilitas, Underwriting, Hasil Investasi dan Dana Tabarru' Terhadap Tingkat Laba pada Perusahaan Asuransi Umum Syariah di Indonesia Tahun 2013-2017 (Doctoral dissertation, Universitas Islam Negeri Sultan Syarif Kasim Riau).

Satata, E. D. A., \& Septiarini, D. F. (2020). Hubungan Premi, Pendapatan Investasi dan Surplus Underwriting Pada Keuntungan PT. Asuransi Jasindo Takaful. Jurnal Ekonomi Syariah Teori dan Terapan, 7(10), 1989-2003. http://dx.doi.org/10.20473/vol7iss202010pp1989-2003.

Scott, R. William. (2000). Financial Accounting Theory. Second Edition. University of Water. Prentince Hall International, Inc.

Triyuwono, I. (2007). Balancing Performance Measurement by Using The Tradition of Islam, Tao, and Java. The International Journal of Accounting and Business Society, 15(1), 1-20.

Utami, A. P. (2018). Pengaruh Komponen Risk Based Bank Rating Terhadap Kinerja Keuangan Bank Umum Swasta Nasional Devisa (Doctoral dissertation, STIE Indonesia Banking School).

Wardani, E. (2019). Faktor-faktor yang Mempengaruhi Kesehatan Keuangan Perusahaan Asuransi Jiwa Syariah pada Tahun 2013-2017. (Yogyakarta: Universitas Islam Negeri Yogyakarta.)

Yermack, D. (1996). Higher market valuation of companies with a small board of directors. Journal of Financial Economics, 40: 185-211. https://doi.org/10.1016/0304-405X(95)00844-5.

Yuniasary, M., \& Nurdin, N. (2019). Pengaruh Sharia Compliance dan Islamic Corporate Governance terhadap Kinerja Keuangan Bank Umum Syariah di Indonesia.

Zeineb, G. B., Mensi, S. (2018). Corporate governance, risk and efficiency: Evidence from GCC Islamic banks. Managerial Finance Journal, 44(5), 551-569. https://doi.org/10.1108/MF-05-2017-0. 